\title{
Effect of Some Sudanese Traditional Hot Iron Branding on Cattle Hide Quality
}

\author{
Rehab Eltejani Abdelkarim, Mohammed Alhadi Ebrahiem*
}

Department of Animal Production, Faculty of Natural Resources and Environmental Studies, University of Kordofan, Elobaied, Sudan

\section{A R T I C L E I N F O}

\section{Article history:}

Received 11 September 2016

Accepted 17 November 2016

Available online, ISSN: 2148-127X

Keywords:

Sudanese tribes

Hot-iron

Branding

Cattle hides

Hide quality

${ }^{*}$ Corresponding Author:

E-mail: mahaali5656@gmail.com \begin{abstract}
A B S T R A C T
This study was designed in order to assess and evaluate the effect of hot iron branding on cattle hide quality. 62 shapes of hot iron branding were detected and classified. Branding damage was evaluated depending on: purpose of application, location in the animal body, branding area, tribe which applied and hide degree. The results showed that, Baggara tribes branding were causing the greater damage on cattle hides; where $71.4 \%$ of its brands placed in the abdominal and animal back area (middle of the hide); in proportion to Misseriya Zuraq tribes (68.4\%). According to the location of branding, the less tribe that causing damages to the cattle hides were Darfur tribes $(14.3 \%)$. In terms of branding area Darfur tribes were causing the most branding damages where $42.8 \%$ of its brands on cattle hides were between $20-30 \mathrm{~cm}$, followed by Baggara tribes where $57.1 \%$ of its brands were between $10-20 \mathrm{~cm}$ then Misseriya Zuraq tribes by $52.6 \%$, and finally North Kordofan tribes of $37.5 \%$. grading of cattle hides depending on the presence of the brand marks the study revealed that, Misseriya Zuraq tribe's brands were obtained the highest percentage $(89.4 \%)$ of the rejected hides (Scarto $=4$ and 5 grades), when compared with North Kordofan tribes $(87.5 \%)$. For commercial reason brand's were mostly done in the area of $5-10 \mathrm{~cm}$ but, their effect on cattle hide quality was greater, where $81 \%$ of the hides were classified as Scarto.
\end{abstract}

\section{Introduction}

Sudan is endowed with a very large livestock population. The animal herd of Sudan was estimated at about 134.57 million heads, being the largest in Africa and Middle East. It consists of about 39.76 million cattle, 48.91 million sheep, 42.18 million goats and 3.72 million camels (MAR, 2004) Based on the quoted figures Sudan ranks on the 7 th place with respect to cattle population, the 6th place on sheep population and the 4th place on goat population worldwide (FAO, 2001).

However, such large stock provides annually a relatively small quantity of hides and skins. There is a wide disparity between the livestock population and the hides or skins output. The main reasons for that been the low off-take of about $6 \%$ for bovine lower than African average $8 \%$ and the lack of meat industry (Rodriguez, 2010). Sudan hides and skins are characterized by a fine quality of its fiber network composition and grain surface which make it suitable for the manufacture of many articles such as garments and gloves (FAO, 1991). Hides and skins represent renewable sources with a great economic value to the Sudan. In spite of this facts, still the production of raw material, hides and skins, is faced by many constraints. Defects always detract from the ability of producing valuable and price-able hides and skins (Habib et al., 2015 and Ebrahiem et al., 2015a and b). This trial was designed to assess and evaluate the effect of hot iron branding which detracting from the potential value and quality of cattle hide.

\section{Material and Methods}

The Study Area

The Study Area North Kordofan State lays between latitudes $11^{\circ} 20^{\prime}$ to $16^{\circ} 36^{\prime} \mathrm{N}$ and longitudes $27^{\circ} 13^{\prime}$ to $32^{\circ} 24^{\prime} \mathrm{E}$ and area occupies an amount to almost 25 million ha. Out of this area, 14.5 million hectares are rangeland (Africover, 2004). The state is considered among the leading regions of Sudan in terms of animal and range resources, where more than million heads of sheep, goat, camel and cattle are raised (RPA, 2005). Animal production in the state is mainly practiced under traditional extensive systems, depending on natural rangeland (Cook and Fadlalla, 1993). The average monthly temperature according to Nimer (2000) was $34.60^{\circ} \mathrm{C}$, and the coldest months were December and January with mean temperatures of $14.10^{\circ} \mathrm{C}$ and $13.50^{\circ} \mathrm{C}$, respectively. The hottest months were April, May and June with an average mean temperature exceeding $40^{\circ} \mathrm{C}$. The soil of the site lies within the sand dune area locally known as "Goz" soil, these soils are inherently poor, but their high permeability and easy penetration of roots, compensate for their inherent poverty (Rabeeh et al., 2015). 


\section{Data Collection}

62 different shapes of hot iron brands on cattle hides were obtained from Elobaied animals market, North Kordofan state, Sudan during the period 2/3/2016 to $3 / 3 / 2016$. The detected shapes of hot iron branding were randomly recorded as photographs images. For this purpose micro digital camera was used. Hot iron brands images then classified depending on: purpose of application, location in the animal body, branding area, tribe which applied and hide degree according to the branding damage.

\section{Statistical Analysis}

The data were analysed using Statistical Package for Social Sciences (SPSS) v.14.0 software package (SPSS, 1996).

\section{Results and Discussion}

Table 1 showed the classification of the traditional hot iron brands on cattle hides to their tribes which applied and reason for implementation. It was clear that branding for commercial or trade reasons represent as the major causes of damages on cattle hides in north Kordofan region. Ebrahiem et al., (2015a) mentioned that Branding damages were clearly observed on hides especially in western parts of the Sudan, where most of meat consumption take-off in this area were from Kordofan and Darfur cattle's. Branding, another important source of damage, is generally used as means of proving ownership, as treatment for some diseases or for superstitious and religious reasons. Hot iron branding is usually applied on cattle hides in the valuable regions as it is observed in cattle of Kordofan and Darfur tribes (Figure 1 and 2).

It observed that, more than $70 \%$ of Baggara tribe's branding was located in the Abdomen and back area, though these brands were affected greater negatively on cattle hides' quality (Figure 3 and 4). In turns most of Misseriya Zuraq tribe's brands (68.4\%) were also implemented in the same area (abdomen and back area), so it comes as 2 nd in detraction of cattle hides quality.
The abdomen and back area are usually the most valuable area of the hide or skin, and it knows as the middle area of the hide or skin and always given the name (butt area). In this area the hide or skin is almost known by it is good quality and uniformed texture (Figure 5 and 6). Ibrahim, (1983) mentioned that large brandings are usually made in the best part of a hide and hence destroy the finished leather of that part. The damage caused by the brand marks could be avoided, if smaller marks were placed on less valuable parts of the hide and would still be equally satisfactory. Branding of native cattle for tribal or religious customs might present greater difficulty because its elimination might be met with strong opposition (Table 2).

Branding for commercial or trade reasons were acting as the greater source of damages to cattle hides. In spite of its small size on cattle $(10-20 \mathrm{~cm}$.), but it has greater effect on cattle hides quality. Whereas $66.7 \%$ of damages were caused as a result of these hot iron brands in comparison to Baggara tribes brands $(57 \%)$ and North Kordofan tribes brands (37\%) for the same brand size (Table 3).

Grading based on hot iron brand marks damages results cleared that more than $89 \%$ of Misseriya Zuraq tribe's branding were caused the deteriorate of cattle hide grade to Scarto grade or reject (4th and 5th grade). North Kordofan State tribe's branding come as the second source of damaging and it was detracted the grade of the hide to Scarto by $87 \%$ (Figure 7). Thus, the above mentioned tribes were detracted from the marketable potential and price-able of the hide as a result of using traditional branding methods. Said et al. (1999) estimated $10-40 \%$ of hide lost as a reason for hot iron branding methods (Table 4).

\section{Conclusion}

In general, traditional hot iron branding has a greater effect on cattle hide quality and it is responsible from about $81-89 \%$ of cattle hides damaging and wasting as Scarto or reject leathers.

Table 1 Classification of the collected brand shapes

\begin{tabular}{l|rr}
\hline \multicolumn{1}{c|}{ Tribe } & No & $\%$ \\
\hline Misseriya Zuraq tribes & 19 & 30.7 \\
North Kordofan tribes & 8 & 12.9 \\
Darfor tribes & 7 & 11.3 \\
Baggara tribes & 7 & 11.3 \\
Commercial brands & 21 & 33.8 \\
Total & 62 & 100.0 \\
\hline
\end{tabular}

Table 2 Brand location on cattle hides

\begin{tabular}{|c|c|c|c|c|c|c|c|c|c|c|}
\hline \multirow[t]{2}{*}{ Brand location } & \multicolumn{2}{|c|}{$\begin{array}{c}\text { Misseriya Zuraq } \\
\text { tribe's }\end{array}$} & \multicolumn{2}{|c|}{$\begin{array}{l}\text { North Kordofan } \\
\text { State tribe's }\end{array}$} & \multicolumn{2}{|c|}{$\begin{array}{l}\text { Darfur } \\
\text { tribe's }\end{array}$} & \multicolumn{2}{|c|}{$\begin{array}{c}\text { Baggara } \\
\text { tribe's }\end{array}$} & \multicolumn{2}{|c|}{$\begin{array}{l}\text { For trade } \\
\text { reason }\end{array}$} \\
\hline & $\%$ & No. & $\%$ & No. & $\%$ & No. & $\%$ & No. & $\%$ & No. \\
\hline Hindquarters & 47.6 & 10 & 0.00 & 0.00 & 14.3 & 1 & 0.00 & 0.00 & 10.5 & 2 \\
\hline Forequarters & 23.8 & 5 & 28.6 & 2 & 71.4 & 5 & 25 & 2 & 15.8 & 3 \\
\hline Abdomen and back & 23.8 & 5 & 71.4 & 5 & 14.3 & 1 & 50 & 4 & 68.4 & 13 \\
\hline Neck & 4.8 & 1 & 0.00 & 0.00 & 0.00 & 0.00 & 0.00 & 0.00 & 0.00 & 0.00 \\
\hline Head & 0.00 & 0.00 & 0.00 & 0.00 & 0.00 & 0.00 & 12.5 & 1 & 5.3 & \\
\hline Total & 100 & 21 & 100 & 7 & 100 & 7 & 100 & 8 & 100 & 19 \\
\hline
\end{tabular}


Table 3 Hot iron brand size on cattle hides

\begin{tabular}{l|rrrrrrrrrr}
\hline \multirow{2}{*}{ Area in cm. } & \multicolumn{2}{|c}{$\begin{array}{c}\text { Misseriya Zuraq } \\
\text { tribe's }\end{array}$} & \multicolumn{2}{c}{$\begin{array}{c}\text { North Kordofan } \\
\text { State tribe's }\end{array}$} & \multicolumn{2}{c}{$\begin{array}{c}\text { Darfur } \\
\text { tribe's }\end{array}$} & \multicolumn{2}{c}{$\begin{array}{c}\text { Baggara } \\
\text { tribe's }\end{array}$} & \multicolumn{2}{c}{$\begin{array}{c}\text { For trade } \\
\text { reason }\end{array}$} \\
\cline { 2 - 11 } & \multicolumn{1}{c}{$\%$} & No. & \multicolumn{1}{c}{$\%$} & No. & $\%$ & No. & $\%$ & No. & $\%$ & No. \\
\hline $10-20$ & 66.7 & 14 & 57.1 & 4 & 28.6 & 2 & 37.5 & 3 & 52.6 & 10 \\
$21-30$ & 33.3 & 7 & 28.6 & 2 & 42.8 & 3 & 37.5 & 3 & 26.3 & 5 \\
$31-40$ & 0.00 & 0.00 & 0.00 & 0.00 & 14.3 & 1 & 25 & 2 & 15.8 & 3 \\
$41-50$ & 0.00 & 0.00 & 14.3 & 1 & 14.3 & 1 & 0.00 & 0.00 & 5.3 & 1 \\
Total & 100 & 21 & 100 & 7 & 100 & 7 & 100 & 8 & 100 & 19 \\
\hline
\end{tabular}

Table 4 Grading of cattle hides depending on hot iron branding

\begin{tabular}{l|rrrrrrrrrr}
\multirow{2}{*}{ Hide grade } & \multicolumn{2}{c}{$\begin{array}{c}\text { Misseriya Zuraq } \\
\text { tribe's }\end{array}$} & \multicolumn{2}{c}{$\begin{array}{c}\text { North Kordofan } \\
\text { State tribe's }\end{array}$} & \multicolumn{2}{c}{$\begin{array}{c}\text { Darfur } \\
\text { tribe's }\end{array}$} & \multicolumn{2}{c}{$\begin{array}{c}\text { Baggara } \\
\text { tribe's }\end{array}$} & \multicolumn{2}{c}{$\begin{array}{c}\text { For trade } \\
\text { reason }\end{array}$} \\
\cline { 2 - 12 } & \multicolumn{1}{c}{$\%$} & \multicolumn{1}{c}{ No. } & \multicolumn{1}{c}{$\%$} & No. & $\%$ & No. & $\%$ & No. & $\%$ & No. \\
\hline Grade 1 & 9.5 & 2 & 0.00 & 0.00 & 12.3 & 1 & 0.00 & 0.00 & 5.3 & 1 \\
Grade 2 & 0.00 & 0.00 & 0.00 & 0.00 & 0.00 & 0.00 & 0.00 & 0.00 & 0.00 & 0.00 \\
Grade 3 & 9.5 & 2 & 14.3 & 1 & 0.00 & 0.00 & 12.5 & 1 & 5.3 & 1 \\
Scarto* & 81 & 17 & 85.7 & 6 & 85.7 & 6 & 87.5 & 7 & 89.4 & 17 \\
Total & 100 & 21 & 100 & 7 & 100 & 7 & 100 & 8 & 100 & 19 \\
\hline
\end{tabular}

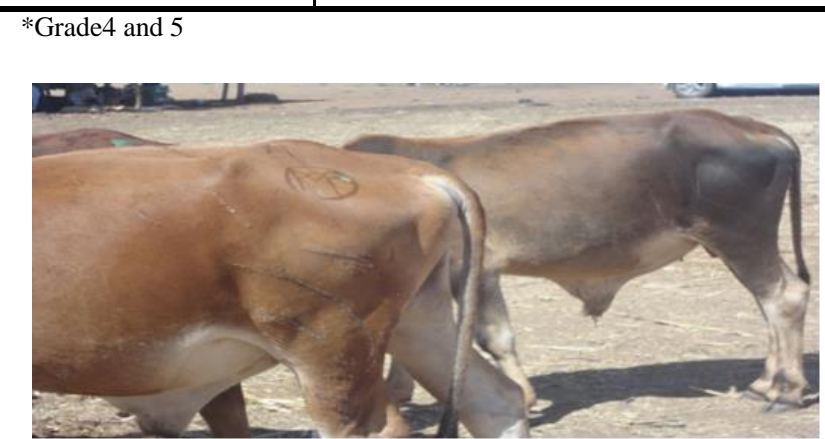

Figure 1 Hot iron branding applied on the hindquarter.

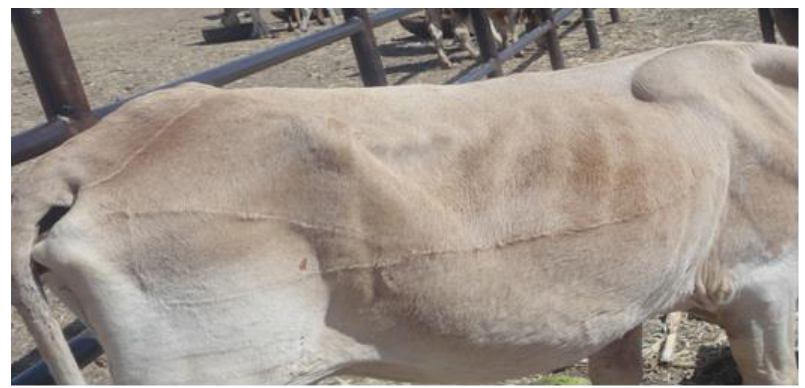

Figure 3 Hot iron branding applied on abdomen and animal back.

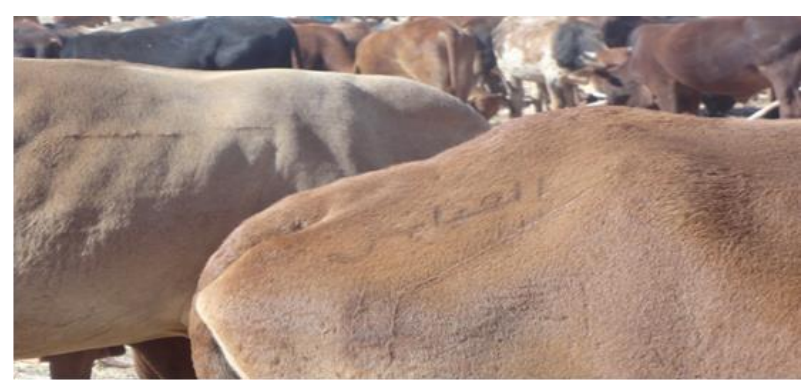

Figure 5 Hot iron branding applied on animal abdomen.

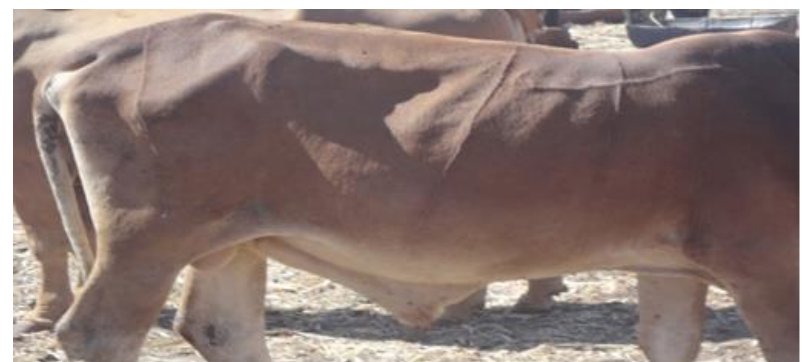

Figure 2 Hot iron branding applied on animal hindquarter and abdomen.

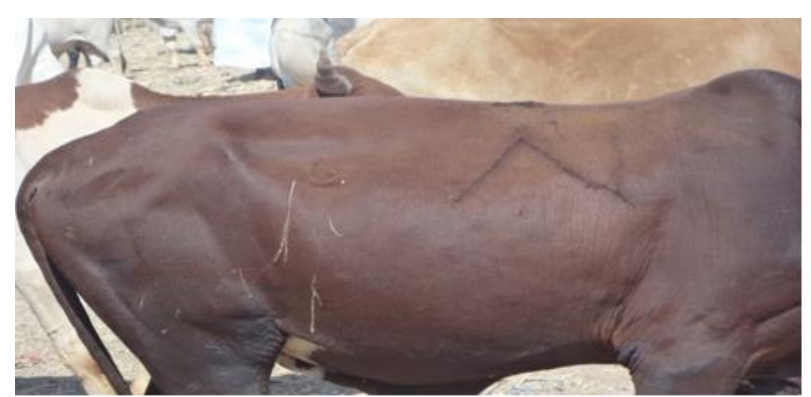

Figure 4 Hot iron branding applied on animal back, hindquarter and abdomen.

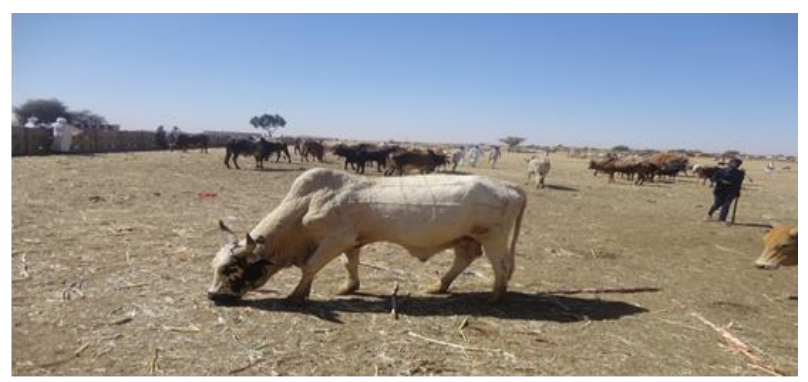

Figure 6 Hot iron branding for trade reason applied on animal hindquarter. 


\section{References}

Africover. 2004. Sudan spatial aggregated map, africover Project, FAO Rome, Italy.

Cook JA, Fadlalla AB. 1993. Season variation in plasma phosphorus Level Of transhumant sheep in Kordofan, Sudan. HI the. Prod, 19:57-62.

Ebrahiem MA, Ali MA, Turki IY, Haroun HE, Bushara I, Mekki DM. 2015a. Grading of Kordofan Hides and Skins by Quality. The Journal of Agriculture and Natural Resources Sciences, 2(2): 401-407. http://www.journals.wsrpublishing.com/ index.php/tjanrs

Ebrahiem MA, Ali MA, Turki IY, Haroun HE, Bushara I, Mekki DM. 2015b. Defects and Grading of Hides and Skins in Kordofan Region, Sudan. The Journal of Agriculture and Natural Resources $\quad$ Sciences, 2(2): 393-400. http://www.journals.wsrpublishing.com/index.php/tjanrs

FAO. 2001.The State of 2001 Food Insecurity in the WorldPublished in 2001 by the Food and Agriculture Organization of the United Nations Viale delle Terme di Caracalla, 00100 Rome, Italy. http://www.fao.org/3/a-y1500e.pdf

FAO. 1991. Trade in hides, skins and their derived products. Workshop- Bulawayo, Zimbabwe.

Habib AB, Noor IA, Musa AE. 2015. Effect of some skin defects on physical properties of the leather. Journal of Applied and Industrial Sciences, 2015, 3 (3): 112-119, (online) http://researchpub.org/journal/jais/number/vol3-no3/vol3-no36.pdf

Ibrahim KE. 1983. Investigations on the defects caused by physical damage, streptothricosis and mange on crust leather and their economical significance in leather industry- B.V.Sc. thesis, University of Khartoum, Sudan.
MAR -Ministry of Animal Resource. 2014. Bulletin for animal resource. Khartoum, Sudan.

Nimer AM. 2000. Effect of Acacia Senegal (L.) Willd., on sandy soils and Assessment of its foliage Nutrient. Case Study of Demokeya forest. Northern Kordofan. M.Sc. Thesis, University of Khartoum, Sudan. http://www.journals.wsrpublishing.com/ index.php/tjanrs

Said AM, Abdelmajed MA, Mohammed AA. 1999. Leather production economy. (study)- Ministry of Animal Wealth and Fishery- General planning and Animal Production Administration- Khartoum, Sudan.

SPSS. 1996. Statistical Packages for the Social Sciences. V.14.0, Cary, North Carolina.

Rabeeh KRS, Abutaba YI, Jadalla JB, Ebrahiem MA. 2015. Impact of continuous grazing around rainy season camping areas on range condition. The Journal of Agriculture and Natural Resources Sciences . 2(1): 355-359.

Rodriguez B. 2010. Supply survey on the leather industry in Sudan. Promoting regional trade in leather and leather Products "Programme for building African capacity for Trade (PACT II) Leather" http://www.intracen.org/uploadedFiles/intracenorg/ Content/About_ITC/Where_are_we_working/Multi-country _programmes/Pact_II/Sudan 